\title{
THE TREATMENT AND THE NEUROLOGICAL ASPECTS OF DIVING ACCIDENTS IN ISRAEL
}

\author{
By Yehuda Melamed, M.D. and Abraham Ohry, M.D. \\ The Naval Medical Hyperbaric Institute, Haifa and The Sir Ludwig Guttmann Spinal Cord \\ Injury Center, Chaim Sheba Medical Center, Tel Hashomer, and Sackler School of Medicine, \\ Tel Aviv, Israel
}

\begin{abstract}
In this paper, the experience with diving accidents and their treatment, accumulated in the Israel Naval Hyperbaric Medical Institute (I.N.H.M.I.) during the past 4 years (I974-1978), has been summarised. Out of the I30 civil diving accidents during these years, were 35 , in whom neurological complications occurred. Two divers were found dead upon surfacing. 33 divers were committed to hyperbaric treatment, 30 of whom recovered completely and only in 3, neurological sequelae remained. (From the analysis of the cases it is concluded that the outcome in these 3 cases is due to delay in the initiation of treatment.) In I 8 cases initial decompression was carried out in a portable one-man chamber as a means of transfer under pressure (pressure stretcher) to a large hyperbaric chamber.

There were II cases with barotrauma (including the 2 immediate deaths) and 24 cases with type II decompression sickness. In the last group cerebral signs predominated. Spinal manifestations occurred in only 4 cases, 2 of which had cerebral symptoms as well. Altogether I 8 patients had been treated in the pressurised one-man chamber as a means of transportation (II with type II decompression, 7 with air emboli due to barotrauma). Six of these were treated with high-pressure oxygen tables while in the small chamber.

It is concluded that immediate hyperbaric treatment is the main factor in ensuring complete recovery from severe diving accidents. The treatment efficiency of a portable one-man chamber is discussed, as well as the safety rules for its operation.

The importance of preventive diving medicine is stressed. Divers should be well informed of the medical risks and the necessary steps to reduce them.

General guidelines to avoid or to improve the treatment of diving accidents are put forward. This is important especially in view of the continuously increasing numbers of sport divers in Israel.
\end{abstract}

Key words: Diving; decompression sickness; barotrauma; spinal cord injury; cerebral injury.

\section{Introduction}

Diving has become a very popular sport in Israel. In I97I, there were only 500 divers, but in 1977 , more than 7000 civilians were diving along the beautiful shores of the Red Sea and the Mediterranean. Nowadays, the Red Sea is one of the world's most popular and attractive diving sites. Many professional and amateur divers from all over the world return year after year to see the fascinating and unique nature in this part of the underwater world.

Until 2 years ago, the Naval Medical Hyperbaric Institute in Haifa was the only one in Israel which could treat all the complications of diving. In this study we summarise the experience in the treatment of diving accidents accumulated during 4 years (1974-1978). All the treatments were given and controlled by the Institute's team. I had the opportunity to follow up some of the divers with neurological complications, but my interest in diving and hyperbaric medicine 
had started earlier when a few of my paraplegic patients participated in a special diving course (Fleming \& Melamed, I974). The neurological involvement appears in the three main diving accident groups. The first group, pulmonary barotrauma, occurs due to pressure dysequilibrium during ascent from diving. Small tears within the alveoli bring air emboli to the large pulmonary veins, then to the left heart, and then mainly to the brain. The cerebral complications may be hemiplegia, loss of consciousness, apnea and cardiac arrest. The second group, decompression sickness, is more complicated. Uncontrolled ascent from diving creates an accumulation of inert gas bubbles in the tissues or blood vessels. In the brain this provokes headaches, vertigo, visual disturbances, loss of consciousness, etc. In the spinal cord this may cause para- or tetraplegia or-paresis. The third group, which will not be discussed here, are the neurological effects of high pressurised nitrogen and prolonged inhalation of air with high oxygen content.

Out of I30 civil diving accidents during these 4 years, neurological complications occurred in 35 and we will mainly discuss them (Melamed, I978).

\section{Material and Methods}

Diving and undersea medicine in Israel is organised and controlled by the Naval Medical Hyperbaric Institute, in cooperation with the Israel Underwater Activities Association. All the patients from diving accidents were treated and controlled at the Institute in Haifa. Most of the diving sites are situated far from Haifa. Therefore, the Institute has trained military and civil medical and paramedical staff, located along the shores of the Red Sea and the Mediterranean, with first-aid equipment and portable one-man chambers. After initial treatment near the diving site, the patients are delivered by helicopter to the big chamber in Haifa for complete treatment. Twenty-one out of 35 accidents involved Israelis and I 4 involved tourists. Most of the accidents happened during spring and early summer in the Red Sea. Most of the divers were amateurs with little experience, and their ages ranged from $2 \mathrm{I}$ to 35 .

\section{Results}

All the patients with neurological complications were committed to hyperbaric treatment. Out of 35 patients, 30 recovered completely and in 3 , neurological sequelae remained. In 18 cases initial decompression was done in a portable one-man chamber as a means of transfer under pressure to a large hyperbaric chamber. There were I I cases with barotrauma (including the two immediate deaths) and 24 cases with type II decompression sickness. In the last group, cerebral signs predominated. Spinal manifestations occurred in only 4 cases, 2 of which had cerebral symptoms as well. Altogether, 18 patients were treated in the pressurised one-man chamber as a means of transportation. Eleven suffered from type II, 7 from air emboli due to barotrauma. Six of these were treated with high-pressure oxygen tables while in the small chamber.

All the accidents were investigated, recorded and fully documented by the Institute.

Table I shows the association between the diving depth and the type of injury. It can be seen that most of the barotrauma accidents with neurological complications happened after relatively shallow-water diving. Decompression sickness and the mixed type happened mainly after deep diving, as shown before.

The clinical picture is shown in Table II. Cerebral injuries usually occurred during rapid surfacing after prolonged bottom-time diving. Non-specific 


\section{TABLE I}

Depth of diving and type of injury

\begin{tabular}{ccccc}
\hline $\begin{array}{c}\text { Depth of diving } \\
\text { (metres) }\end{array}$ & $\begin{array}{c}\text { Barotrauma with } \\
\text { neurological } \\
\text { complications }\end{array}$ & $\begin{array}{c}\text { Decompression } \\
\text { sickness with } \\
\text { neurological } \\
\text { complications }\end{array}$ & $\begin{array}{c}\text { Mixed } \\
\text { type }\end{array}$ & Total \\
\hline Up to I2 & 3 & - & - & \\
I2-20 & 2 & I & - & \\
$20-30$ & - & 5 & - & \\
$30-50$ & 4 & I0 & - & \\
$50-70$ & 2 & 24 & 2 & 37 \\
Total & I I & & & \\
\hline
\end{tabular}

\section{TABLE II}

Decompression sickness: clinical signs

\begin{tabular}{cccccccc}
\hline $\begin{array}{c}\text { Max. diving } \\
\text { depth } \\
(\mathrm{m})\end{array}$ & $\begin{array}{c}\text { Bottom time } \\
\text { in minutes } \\
\text { (min.-max.) }\end{array}$ & $\begin{array}{c}\text { Spinal } \\
\text { signs }\end{array}$ & $\begin{array}{c}\text { Cerebral } \\
\text { signs }\end{array}$ & $\begin{array}{c}\text { Respira- } \\
\text { tory }\end{array}$ & $\begin{array}{c}\text { Vestibular } \\
\text { signs }\end{array}$ & $\begin{array}{c}\text { Cerebral } \\
\text { and } \\
\text { spinal }\end{array}$ & $\begin{array}{c}\text { Non- } \\
\text { specific } \\
\text { signs }\end{array}$ \\
\hline I2-20 & $60-150$ & - & - & - & - & - & I \\
$20-30$ & $25-60$ & - & I & & & I & 2 \\
$30-50$ & $25-35$ & 2 & 7 & I & I & I & I \\
$50-70$ & I0- 40 & & 6 & & & & \\
Total-24 cases & 2 & I 4 & I & I & 2 & 4 \\
\hline
\end{tabular}

TABLE III

Decompression sickness. The time of appearance of neurological signs after emerging from water

\begin{tabular}{rc}
\hline Time & No. of cases \\
Immediate & 2 \\
$0-5 \mathrm{~min}$. & $\mathrm{IO}$ \\
$5-30 \mathrm{~min}$. & 4 \\
$30-60 \mathrm{~min}$. & 2 \\
I- $2 \mathrm{hr}$. & 3 \\
$2-6 \mathrm{hr}$. & - \\
$6-12 \mathrm{hr}$. & - \\
I2-24 hr. & - \\
$24-36 \mathrm{hr}$. & $\mathrm{I}$ \\
$36-48 \mathrm{hr}$. & 24 \\
Total & \\
\hline
\end{tabular}


complaints included bizarre feelings, fatigue, diffuse pain, etc. Table III shows the time elapsed between immersion and the appearance of neurological signs in the decompression group. Most of the neurological signs due to type II decompression appeared during the first 30 minutes after surfacing, but signs may appear up to 36 hours after diving (as was also reported by Eliot, 1974). In the barotrauma group, most of the neurological signs appeared immediately after surfacing, and up to 30 minutes later (Table IV), as reported by Twose (I972).

\section{TABLE IV}

The Barotrauma Group. The time elapsed between end of diving and appearance of neurological symptoms

\begin{tabular}{lc}
\hline Time & No. of cases \\
\hline Immediate & 9 \\
Up to Io min. & I \\
48 hr. & I $^{\star}$ \\
Total & I I \\
\hline \multicolumn{2}{c}{ * Hysterical case. }
\end{tabular}

\section{Case Reports}

A 25-year-old professional diver was working 36 metres under water, with a bottomtime of 32 minutes. Then he began to ascend and stopped at 3 metres for I 4 minutes. Right after surfacing he complained of neck pain, general fatigue and paresthesias. $\mathrm{He}$ immediately dived again (wrongly) for decompression, but his situation worsened.

He was delivered to the shore after 20 minutes. Neurological examination revealed hyper-reflexia of the achilles and patellar tendons, clonus, pyramidal signs and decrease of lower limbs power. Decompression was started in the small chamber (treatment Table IV) for I50 minutes and I hour later he was delivered by helicopter to Haifa. During the transfer to the big chamber the patient felt good. He had paresthesias, Di2 hypoesthesia and normal cardiovascular status. Five hours after the accident his laboratory findings were as follows; $2.9 \mathrm{mEq} / 1$ potassium, I42 mEq/ 1 sodium, II 2 chloride and $28 \mathrm{CO}_{2} \mathrm{CP}$. I gr corticosteroids, $500 \mathrm{ml}$ Dextran 40, $20 \mathrm{mg} \mathrm{Lasix}$ and $500 \mathrm{ml}$ Manitol were administered intravenously. After two 'rounds' of hyperbaric treatment his neurological state worsened and evolved slowly to incomplete $\mathrm{C}_{4}$ (I5 quadriplegia). At this time the laboratory data revealed marked polycythemia $(\mathrm{I} 8.5 \mathrm{gr} \% \mathrm{Hb}), 20 \mathrm{mg}$ urea, $4.3 \mathrm{mEq} / 1$ potassium and $135 \mathrm{mEq} / 1$ of sodium. Near the end of the hyperbaric treatment his problems were quadriplegia and respiratory insufficiency. He was treated later with oxygen, corticosteroids and antibiotics, and he almost recovered. Now, more than 2 years after the injury, he has some weakness of the extremities, partial sphincter paralysis, but he walks without aids. Our conclusion is that his neurological outcome was such because of the 2-hour delay in transportation to the small chamber.

The other case ended in a cauda equina syndrome. He dived for sport, and due to rapid surfacing, developed type II decompression sickness with paraplegia. Because of the delay in delivery to the large chamber, his neurological status did not change significantly. The laboratory data also showed hypokalemia with polycythemia.

\section{Discussion}

It is obvious that pure spinal lesion due to diving accidents is quite rare. The mechanism behind neurological manifestations of barotrauma is clear. Because of 
pressure dysequilibrium, alveoli tears lead to broncho-pleural fistulae, bronchoalveolar-venous fistulae, pneumothorax, pneumomediastinum and subcutaneous emphysema. Air emboli enter the blood vessels and travel to the brain, causing various neurological pictures (Strauss, 1976). The signs and symptoms seen in our patients consisted of: hemiparesis or hemiplegia, visual disturbances, loss of consciousness, apnea, vomiting, decerebration and death due to cardio-pulmonary arrest. The clinical picture (pulmonary and neurological manifestations) appears right after surfacing (Schaefer \& McNulty, 1958). Decompression sickness is a complication of healthy young divers. It results from a reduction of the environmental pressure sufficient to cause bubble formation from gases dissolved in tissues (Hallenbeck et al., 1975). As early as I670, Sir Robert Boyle had recognised the potential of intravascular and extravascular bubbles as causative agents in the convulsive death of the animals he had exposed to low barometric pressure (Boyle, I670). Until I908, when Boycott and Haldane recognised the possibility of 'Caisson disease at very low pressure', the literature was chiefly concerned with hyperbaric conditions. But in addition to naval and commercial divers, high altitude personnel and compressed air workers are also exposed to decompression sickness. Up to 34 per cent of all cases of decompression sickness due to diving show some kind of neurological complication. In the course of severe decompression sickness leading to spinal cord damage, regions of the epidural vertebral venous system (of Batson) communicate with cranial dural sinuses, with the posterior bronchial and parietal-pleural veins, with the ascending lumbar veins in the abdomen and with the azygos and the vertebral veins in the thorax and neck.

The flow rate in this valveless system is very slow and the direction of the flow changes frequently. Bubbles collect, grow or coalesce and obstruct this system more frequently than the cranial or cerebral veins. It is obvious that most bubbles grow in the adipose tissues and that their effect is also due to a 'space occupying lesion' mechanism. The polycythemia observed in these patients is partially explained by the effect of contact between bubbles and blood (Freeman \& Phillip, 1976). The results are protein and enzyme denaturation, fat emboli, platelet sludging and aggregation, clotting and fibrinolytic system activation, bradykinine-histamine release, hemoconcentration, and hypovolemia.

Most of the spinal cord injuries seen in type II decompression sickness are at the level of the thoracic segments, but lumbar and cervical segments are not immune against it (Elliot, 1974; Hallenbeck et al., 1975; Frankel, 1977). Despite hyperbaric treatment, the level of the lesion ascends occasionally, probably due to local oedema, as was seen in the two above-described patients. The white matter is damaged more frequently than the grey one. The cerebral signs seen in our (decompression sickness) patients were visual disturbances, nystagmus, severe headaches, nausea, vomiting and loss of consciousness. Spinal signs were weakness of extremities, parethesias, para- or tetraplegia. Abdominal pain may precede spinal signs. Pulmonary signs consist of dyspnea with extreme anxiety (the 'chokes'). The inner ear may also be involved, showing vertigo and hearing loss.

\section{Conclusions}

I. The civilian diving accidents rate increases constantly.

2. Immediate hyperbaric treatment is the main factor in ensuring complete neurological recovery from severe diving accidents.

3. Permanent spinal cord damage due to decompression sickness is rare. 
4. The initial treatment with portable one-man chambers near the diving site is mandatory.

5. The main causes of civilian diving accidents are negligence and confusion.

6. The best treatment is prevention. Divers should be well informed about the medical risks and the necessary steps to reduce them.

\section{RÉSUMÉ}

Dans cette étude, l'expérience accumulée en 4 ans (1974-1978) à l'Institut Naval Israelien de Médecine Hyperbarique au sujet des accidents de plongée et de leur traitement est passée en revue. 35 accidents compliqués par des séquelles neurologiques sont analysés. Deux plongeurs furent trouvés morts à leur remontée. Sur 33 plongeurs qui reçurent le traitement hyperbarique 30 guérirerit completement alors que 3 plongeurs conserverent des séquelles neurologiques. Il est conclu que ces 3 derniers cas sont dus a un delai dans le début du traitement.

Dans I8 cas la recompression initiale fut effectuée dans une cellule portable a une personne, comme moyen de transport sous pression jusqu'a une grande chambre hyperbarique. Les avantages de cette cellule sont discutes.

Il est conclu qu'un traitement hyperbarique immediat est le facteur principal d'une guerison complete dans les accidents de plongée graves. Les causes des accidents de plongée civils en Israël sont discutées extensivement. Des directives sont données pour prevenir et mieux soigner ces accidents, ce qui est particulierement important vu l'augmentation constante du nombre de plongeurs sportifs en Israël.

\section{ZUSAMMENFASSUNG}

Die 4 Jahre-lange (1974-I978) Erfahrung des Israelischen Seeinstitutes fur Hyperbarische Medizin mit Tauchunfallen und ihrer Behandlung wird beschrieben. 35 Unfälle mit neurologischen Folgen werden analysiert. Zwei Taucher wurden bei ihrem Wiederaufstieg tot gerfunden. Von 33 Tauchern die hyperbarisch behandelt wurden konnten 30 vollkommen geheilt werden und nur 3 behielten neurologische Folgen. Diese 3 Falle sind dem spaten Behandlungsanfang zugeschrieben.

In I 8 Fällen wurde die erste Rekompression in einer tragbaren Kammer fur eine Person durchgeführt, als Beförderungsmittel unter Druck bis zur grossen hyperbarischen Kammer. Die Vorteile der kleinen Kammer sind hier diskutiert.

Eine vollkommene Genesung bei schweren Tauchunfällen hängt von der sorfortigen hyperbarischen Behandlung ab. Die Gründe ziviler Tauchunfälle in Israel sind extensiv diskutiert. Es werden Anleitungen gegeben, um diese Unfälle zu vermeiden und besser zu behandeln, was besonders wichtig ist wegen der dauernd steigenden Anzahl von Sporttauchern in Israel.

\section{REFERENCES}

Boycott, A. \& Haldane, J. S. (I908). The effects of low atmospheric pressures on respiration. F. Physiol. 37, 355.

Boyle, R. (I670). New pneumatical experiments about respiration. Philos. Trans. 5, 20 I I.

Elliott, D. H. (1974). Acute decompression sickness. Lancet, I, I I93.

Flemming, N. C. \& Melamed, Y. (I974). Diving for the disabled. B.S.A.C. Officers Conference, Stoke Mandeville.

Frankel, H. (I977). Paraplegia due to decompression sickness. Paraplegia, 14, 306.

Freeman, D. I. \& Phillip, R. B. (I976). Changes in blood enzymes activity and hematology of rats with decompression sickness. Aviat. Space Environ. Med. 47, 945.

Hallenbeck, J. M., Bove, A. A. \& Elliott, D. H. (I975). Mechanisms underlying spinal cord damage in decompression sickness. Neurology, 25, 308.

Melamed, Y. (I978). The treatment and the neurological aspects of diving accidents in Israel. M.D. Thesis.

SChaEFER, K. E. \& MCNully, S. P. (1958). Mechanisms in development of interstitial emphysema and air embolism on decompression from depth. F. Appl. Physiol. 13, I5.

Strauss, R. (1976). Diving Medicine. Grune \& Stratton, N.Y.

Twose, J. (1972). Accidents-Incidents. Royal Naval Physiology Laboratory, Diving Officers Conference. 